\title{
Promoting of Development with the Assistance of Financial Technology
}

\author{
Li Zhang \\ School of Finance and Accounting \\ Fuzhou University of International Studies and Trade \\ Changle, China \\ czzhangli@126.com
}

\author{
Nan Lin* \\ Teaching Quality Management Center \\ Fuzhou University of International Studies and Trade \\ Changle, China \\ nanlin36@126.com
}

\begin{abstract}
The financial service system has always served for urban families and companies. The kinds of financial products and services for the rural areas are very poor. Therefore, it is meaningful to promote the development of rural inclusive finance to improve the urban-rural dual structure. The convenience and accessibility of financial services can play important role for the rural vulnerable groups. Financial technology refers to the dynamic integration of financial services and technology industry. The innovation of financial products and services based on technology will help to reduce financial costs and promote the leap-forward development of rural finance. Rural financial infrastructures have needed to be improved, and farmers have generally got lower education degrees with a vague understanding of financial knowledge. Financial technology can help rural financial innovations in many aspects, so it is necessary to embed financial technology into rural financial services. Fintech would be useful to improve the financial environment for agriculture, rural areas and farmers. Moreover, it can improve the efficiency of rural financial services, and establish a rural credit information system.
\end{abstract}

Keywords-rural; financial technology; inclusive finance; financial regulation

\section{INTRODUCTION}

In developing countries, the development of the agricultural sector is important for the following reasons. The most obvious one is that agriculture is still a source of livelihood for a majority of people in rural areas [1]. It can be seen that the required growth of productivity in agriculture means that more capital must be invested in it. Farmers need much more capital than they can afford to save to help them to keep the ability in production progresses. Hence, the financial routines are also necessary for farmers groups which they could not be access easily [2].

Furthermore, the income gap between urban and rural areas has become more apparent with the rapid development of the economy [3]. The issues about "agriculture, rural areas and farmers" have always been the focus of social attention. Nowadays, the development of rural finance has gradually become an important way to narrow the income gap between urban and rural areas. Furthermore, it can promote economic development effectively. The financial technology service plays a great role in promoting the development of finance in rural areas [4].
It can not only contribute to the innovation of rural financial products and management of rural financial risks, but also helps to expand the coverage of financial services. In addition, financial policies and knowledge can be popularized in rural areas due to the progress of financial technology services [5]. The promotion of rural economic development by financial technology is an urgent need to achieve social fairness and justice. It is also the final purpose of inclusive finance [6]. The future of rural finance must be a form evolved with the development of financial technology. With the help of financial technology, future rural finance may break away from the traditional form and take advantage of the combination of science technology and finance to energize financial ways.

\section{The Definitions About RuRal InClusive Finance and FinanCial SCIENCE AND TeChNOLOGY}

\section{A. Rural Inclusive Finance}

Inclusive finance refers to the democracy and equality of financial services. Its goal is to offer equal opportunities to all groups of the social class to access to financial services. In the rural financial system, rural residents who have always been weak in economic situations and had not a good credit basis could not meet the loan requirements of financial institutions such as commercial banks [7]. However, these vulnerable groups also need financial services to change the current economic situations. Therefore, the development goal of rural inclusive finance is to provide financial services of consumption or production to the vast micro-subjects in rural areas.

\section{B. Fintech}

"Fintech" is the abbreviation of financial technology which has gotten a lot of attention in recent years [8]. Moreover, the definitions of concept of fintech are not similar due to the different stages of financial development in different countries. The definition of fintech from the Financial Stability Board (FSB) which refers to the financial innovation brought by technology is generally accepted by the people of financial industries [9]. It can create new business models, applications, processes or products with major impacts on the financial markets, financial institutions or financial services. However, the "fintech" is not the same as "Internet finance", which they are easy to be misunderstood by some people [10]

The research was sponsored by the educational research projects for young and middle-aged teachers in Fujian in 2017 (JAS170706). 
successively signed the financial technology strategic cooperation agreements with the four major Internet giants which are called BATJ. The combination of technology companies and traditional banks will jointly create technological services for rural areas. More and more institutions have focused on this huge market with the growing demand for rural financial services. However, rural finance can be described as difficult in the process of advancement. China's "three rural issues" have always been complicated due to regional differences, urban-rural differences, and extremely diversified market demands. Hence, there is great feasibility and necessity to embed financial technology into rural financial services. The combination between technology companies and traditional financial institutions which have their own expertise in their respective fields of business should lead to the leapforward development of traditional rural financial services.

However, the overall rural inclusive finance system for all rural areas have not been finished. Hence, the incomplete information from the rural financial system cannot be used for the financial market effectively, which means the rural financial system cannot be associated with the national financial market to get the full functions. And the fintech could solve this problem by using big data and blockchain technologies.

\section{B. The Lacking Financial Knowledge for Farmers}

The rural financial institutions have successively offered lending services for agriculture supporting under the guidance of national policies [12]. The Internet platforms of different financial institutions have also seized the opportunity to continuously meet the financial needs of modern agriculture which include lending, money management and other aspects. However, the average lower education degree of the farmer group leads the rural financial market more difficult to be entered in. Farmers' understandings about financial knowledge, related financial products and services are still not enough. It has hindered the development of rural finance in China.

\section{The Obstacles of Rural Inclusive Financial System Implementing}

Some important government meetings point out it is necessary to speed up the establishment of rural inclusive financial systems and innovate rural financial system to accelerate the development of rural inclusive finance. At the same time, a series of support policies have been implemented which include tax-free policies for rural financial services, financial subsidies for poverty alleviation loans and establishment of rural inclusive financial systems. However, the implementation of policies has been not been effective. The farmers cannot be able to understand relevant policies in time with the ineffective information spreading and measures implementing because of the cost constraints of rural financial institutions.

\section{THE FUNCTIONS OF FINANCIAL TECHNOLOGY IN RURAL INCLUSIVE FINANCE}

Financial technology can help innovations of rural financial services in many aspects, which can be called "a historic opportunity" for development of rural finance in the new era. In 2017, the four major state-owned commercial banks

\section{A. Using Financial Technology to Improve the Rural Financial Environment}

There are still many rural areas without modern financial services that are in a limited environment. Commercial banks can carry out inclusive financial innovations through fintech to face the complex rural environment. The approaches such as mobile financial product development and mobile phone ecommerce trading systems of rural areas could be used to improve the rural financial environment. The approaches can bring the services which include new rural insurance, new rural cooperatives, agricultural subsidies to rural area to create a "mobile wallet" for farmers. Moreover, e-commerce supply chain finance is also a beneficial branch and supplement of financial technology services for rural residents. With the popularization of rural e-commerce, banks can promote the development of financial technology in rural areas. In addition, the additional transaction data of e-commerce product transactions and supply chain might reduce the bank risktaking and improve the accuracy of credit evaluation.

\section{B. Using financial technology to improve the efficiency of rural financial service}

Commercial banks can apply new technologies such as the Internet, big data, and artificial intelligence to the field of investment and wealth management based on the fintech platforms to offer the convenient services for rural families. Generally, the commercial banks could not set up their branches all over the rural areas which should need too much cost. The fintech with financial services can be suitable for situations and beneficial for both financial institutions and farmers. The most obvious application is that they can design some Internet wealth management products with low investment threshold, transparent information, and simple and standardized operation. The products can be sold by the mobile financial platform which has used fintech. The applications such as Weibo and WeChat can rely as marketing approaches for those financial products designed for rural families.

\section{Using financial technology to establish a rural credit system}

Efficient and convenient credit financing services are inseparable from the support of a sound credit system. Fintech could be used to establish a rural credit system to generate 


\section{CONCLUSION}

value for farmers' credit. For banks, it is beneficial to improve their risk management capabilities by providing fintech-based big data credit assessment services. The credit data can be collected from the Internet financial institutions such as Ali Pay, government departments, and rural commodity service providers. The information could cover farmers' production, income, consumption and assets, which can evaluate each farmer's credit accurately value. The rural credit system can help to maintain the activeness of rural financial markets.

\section{SugGestions to PROMOte RuRAL FinANCIAL DEVELOPMENT WITH FINANCIAL TECHNOLOGY SERVICES}

\section{A. Using technology to reduce the business costs of financial institutions}

The obstacles of traditional rural financial development mainly focus on the high construction cost of branches, low returns and low market concentration. The product promotions, services delivery or financial knowledge popularization would cost a lot of money. Financial technology can solve these problems more conveniently. Mobile Internet technology can reduce the costs of financial institutions on network construction. Moreover, it can also increase the coverage of outlets, and reduce the operating costs of rural financial institutions.

\section{B. Utilizing Internet technology to popularize inclusive financial education}

The technology can greatly reduce the barriers to farmers' access to financial services and make more farmers understand the financial industry. The traditional financial education should be inefficient and time-consuming, but the use of Internet technology can come true to the goal of financial knowledge promotion efficiently and conveniently in rural areas. The advancing of financial technology could offer better services for farmers only if farmers understand these services and know the importance of finance. Therefore, the promotion of financial knowledge is important. Financial institutions should use the existing communication facilities to implement this process, so that financial technology can be truly promoted in rural areas.

\section{More strict government financial supervision}

The financial supervision should be focused to make a good financial market order. Appropriate laws and regulations should be proposed for each financial development step. The fintech could raise more potential risks in the market while it brings convenience services. In the past two years, many companies with the "slogan" of financial technology have used the Internet to raise funds, which is illegal. For example, the P2P companies had been popular in the past two years which brought huge losses to the market and investors. There should be corresponding supervision in promoting financial technology and improving financial services. The financial prevention awareness of rural families is evenly much weaker than urban families. It should pay more attention to regulatory issues and protect farmers' rights and interests when financial technology elements are jointed in the rural financial market.
The development of financial markets is mainly concentrated in cities because of the more developed economy and denser population. In addition, the high cost of rural financial market development and the low expected return of rural financial services are also important factors. However, it is necessary to pay attention to rural financial development to eliminate the urban-rural gap and allow rural families to enjoy the benefits of economic development. Moreover, it is also the policy orientation of the government. With the development of financial technology, it can effectively solve the problems of high cost of rural financial market development, the insufficient return of financial institutions, and lacking financial knowledge of farmers. The financial technology should be used effectively to support the beautiful vision of a comprehensive well-off society with the development of rural financial markets. And the financial knowledge diffusion with internet, a sound rural financial credit system and a suitable supervision system should be considered to support the financial technology used in the rural financial market.

\section{REFERENCES}

[1] Singh, S, "Micro Finance for Agriculture in Asia: Can it Deliver? ”Millennial Asia, 2010, 1(2), pp.241-269.

[2] Jonathan Conning, Christopher Udry, "Rural Financial Markets in Developing Countries,” Working Papers 914, Economic Growth Center, Yale University, 2005.

[3] John W. Schindler, "FinTech and Financial Innovation: Drivers and Depth,” Finance and Economics Discussion Series, Board of Governors of the Federal Reserve System (US), 2017-081.

[4] Meyer. Richard L, Blanco. Rhenee, "Rural Deposit Mobilization in the Philippines,” Working Papers WP, Philippine Institute for Development Studies, 1988-15.

[5] Peter J. Barry, Paul N. Ellinger, "Liquidity and competition in rural credit markets," Proceedings of Rural and Agricultural Conferences, Federal Reserve Bank of Kansas City, 1997, pp. 47-77.

[6] Anand Bansal, "Financial Sector Reforms And Rural Financial Markets In India,” Journal of Academic Research in Economics, Spiru Haret University, Faculty of Accounting and Financial Management Constanta, vol. 7(3 Dec), 2015, pp. 345-357.

[7] S. M. Jawed Akhtar and Saba Parveen, “Agriculture, Inclusive Growth and Financial Inclusion: An Interrelated Phenomenon," Transnational Corporations Review, Ottawa United Learning Academy, 2014, vol. 6(2), pp. 171-183.

[8] Hung, J.-L, B. Luo, "FinTech in Taiwan: a case study of a Bank's strategic planning for an investment in a FinTech company.” Financial Innovation 2016, 2(1), pp. 345-357

[9] Block, W. E, “Micro - finance: a critique.” Humanomics, 2012, 28(2), pp.92-117.

[10] S. Chandrasekhar, "Reading the tea leaves on financial inclusion: The Case of rural labor households,” Indira Gandhi Institute of Development Research, Mumbai Working Papers, Indira Gandhi Institute of Development Research, Mumbai, India, 2014-003.

[11] Swamy. Vighneswara, "Reforms in Institutional Finance for Inclusive Growth,” MPRA Paper 58337, University Library of Munich, Germany, 2014.

[12] Treleaven. Philip (2015). "Financial regulation of FinTech,” Journal of Financial Perspectives, EY Global FS Institute, 2015, vol. 3(3), pp. 114121 